\title{
The influence of the chosen welding technology on the microstructure and selected mechanical properties of welded magnesium alloy AZ91
}

\author{
Wpływ technologii spawania na mikrostrukturę i wybrane \\ właściwości mechaniczne złączy spawanych stopu AZ91
}

\begin{abstract}
Magnesium alloys are a part of a group of lightweight alloys, which are important in practical use in constructions. The paper shows the results obtained by research into weIded AZ91 magnesium alloy. Within the scope of research microstructure examination and tensile testing were done. Magnesium alloy was welded by two methods - 141 (TIG) and 522 (laser gas welding). The values of tensile strength of welded joints in majority cases were higher than values of tensile strength of the base material. The microstructure examination and chemical analysis made it possible to explain the phenomena occurring in the AZ91 during welding.
\end{abstract}

Keywords: AZ91 magnesium alloy; welding, mechanical properties; microstructure; welded joint

\section{Streszczenie}

Stopy magnezu należą do grupy stopów metali lekkich, używanych $w$ konstrukcjach. W artykule przedstawiono wyniki uzyskane w czasie badań złączy spawanych stopu AZ91. Wykonane zostały: obserwacja mikrostruktury i próba jednoosiowego rozciągania. Złącza zostały wykonane metodą 141 (TIG) i 522 (spawanie laserem gazowym). Wartości wytrzymałości na rozciąganie złączy spawanych $w$ większości przypadków były wyższe niż wartości tych wielkości w przypadku materiału rodzimego. Badania mikrostruktury i składu chemicznego pozwoliły wyjaśnić zjawiska zachodzące w stopie podczas spawania.

Słowa kluczowe: AZ92; stopy magnezu; spawanie; właściwości mechaniczne; mikrostruktura; złącze spawane

\section{Introduction}

Magnesium is one of the lightest metals [1] (density 1.74 $\mathrm{g} / \mathrm{cm}^{3}$ - approximately fourfold lighter material than a steel [2]) of all practical engineering materials. Magnesium alloys have high specific strength, and exceptional mechanical properties in comparison to its low density. These properties are: high strength and high elasticity. In the recent years, magnesium alloys, due to their relatively low mass, have been of an increasingly big interest mostly to the automotive industry.

The basic methods used for welding the magnesium alloys are: 141 (TIG), 131 (MIG) and 52 (laser welding).

The adequate preparation of elements before welding is essential. Incorrectly cleaned ends can cause lack of fusion and anomalous wetting.

Difficulties with welding the magnesium alloys result from the following factors [3]:

- high chemical reactivity between magnesium and oxygen. Magnesium oxides which have melting point $2500^{\circ} \mathrm{C}$, inhibit the welding process;

- high thermal conductivity;

- low melting point;
- the colour of material do not change during heating before welding;

- brittleness of a few magnesium alloys in temperature higher than $400^{\circ} \mathrm{C}$;

- low tensile strength of few magnesium alloys in temperature higher than $500{ }^{\circ} \mathrm{C}$;

- low temperature of evaporation of the magnesium $\left(1090^{\circ} \mathrm{C}\right)$;

- flammability of magnesium.

Alternating current and direct current with positive polarity can be used for welding in 141 method. Direct current with negative polarity should not be used because magnesium oxides cannot be removed from the surface of material [3].

\section{Research methodology}

\section{Tensile testing}

Tensile testing was realized in order to determine the tensile strength of the base material and the welded joints. Specimens were extracted from the base material

Mgr inż. Paweł Bolanowski; prof. dr hab. inż. Andrzej Dziadoń - Politechnika Świętokrzyska.

Autor korespondencyjny/Corresponding author. pawelbolan@wp.pl 
and the joints welded by using both methods. Next they were prepared by machining. Three specimens of each type were used for testing. The technical drawing of sample is shown in Fig. 1 and Fig. 2.

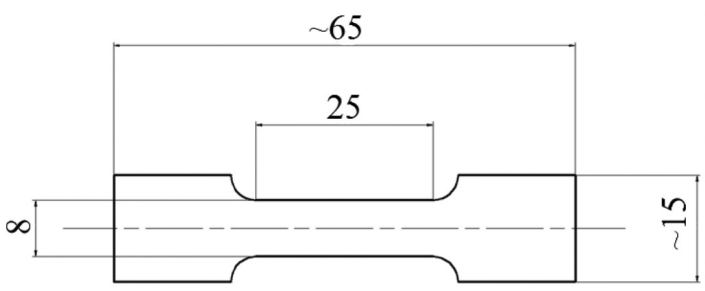

Fig. 1. The technical drawing of specimen for tensile testing cut from welded joints

Rys. 1. Schemat próbki do próby jednoosiowego rozciągania pobrana $z$ materiału rodzimego

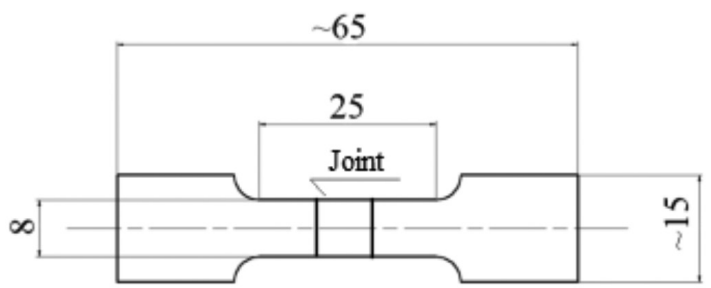

Fig. 2. The technical drawing of specimen for tensile testing cut from base material

Rys. 2. Schemat próbki do próby jednoosiowego rozciągania pobrana ze złączy spawanych

\section{Microstructure examination}

The fragments of welded joints were specimen used for microstructure examination. Extracted specimens was machined and prepared for the metallographic examination in the grinder-polisher produced by Struers. The silica colloidal was etching reagent used for revealing the microstructure of welded joints. The microstructure was observed using an MA-200 (light microscope) and NEXUS 400 (SEM).

\section{Material}

The fragments of casted magnesium alloy AZ91 were used as the base material. The chemical composition of AZ91 accordant with ASTM B93/B93M standard is given in Table 1.

The $\mathrm{Mg}$ - Al phase diagram is shown in Fig. 3. [4]

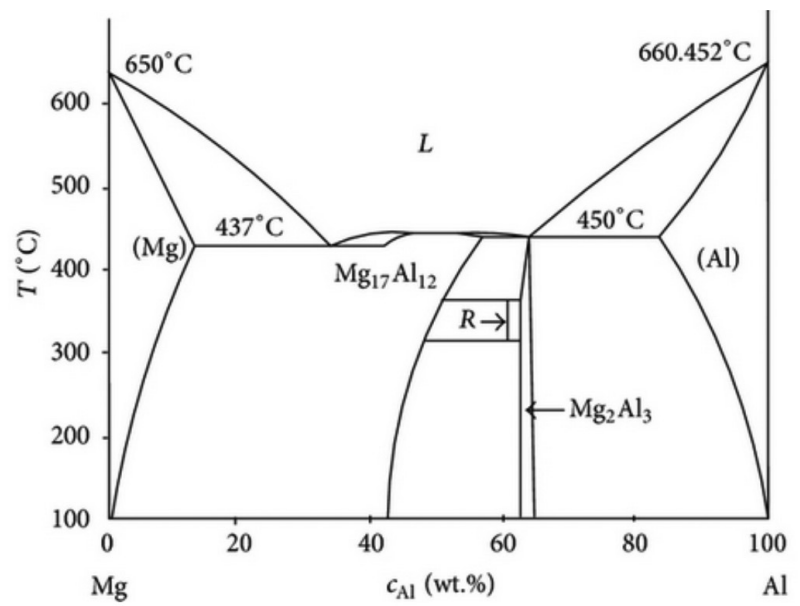

Fig. 3. The $\mathrm{Mg}$ - Al phase diagram

Rys. 3. Układ równowagi Mg-Al
Table I. The chemical composition of AZ91

Tablica I. Skład chemiczny stopu AZ91

\begin{tabular}{|c|c|c|c|c|c|c|c|}
\hline \multirow{2}{*}{ Cast } & \multicolumn{7}{|c|}{ Chemical composition [\%] } \\
\cline { 2 - 8 } & $\mathrm{Al}$ & $\mathrm{Zn}$ & $\mathrm{Mn}$ & $\mathrm{Si}$ & $\mathrm{Fe}$ & $\mathrm{CU}$ & $\mathrm{Ni}$ \\
\hline \multirow{2}{*}{$\mathrm{AZ91}$} & $\begin{array}{c}8,5- \\
9,5\end{array}$ & $\begin{array}{c}0,45 \\
-0,9\end{array}$ & $\begin{array}{c}0,15- \\
0,4\end{array}$ & 0,08 & 0,004 & 0,025 & 0,001 \\
\hline
\end{tabular}

The microstructure of AZ91 magnesium alloy is shown in Fig. 4 and Fig. 5.

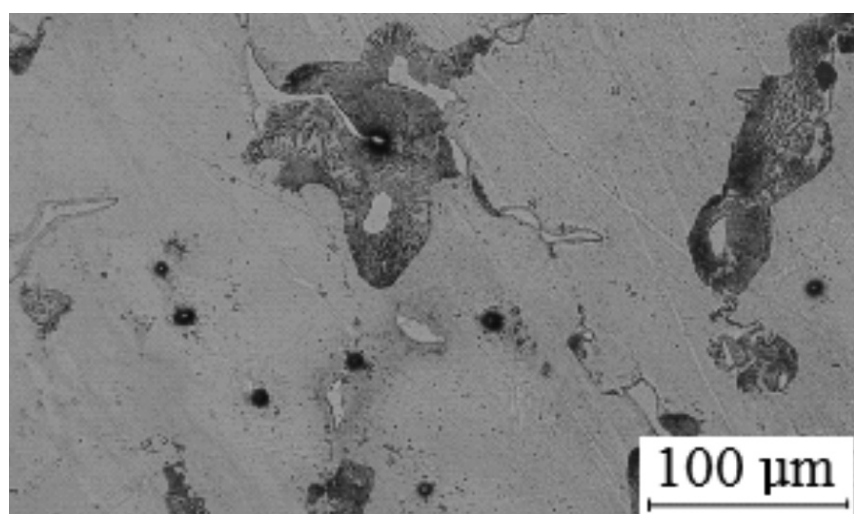

Fig. 4. The microstructure of the base material - AZ91 magnesium alloy

Rys. 4. Mikrostruktura materiału rodzimego - stop magnezu AZ91

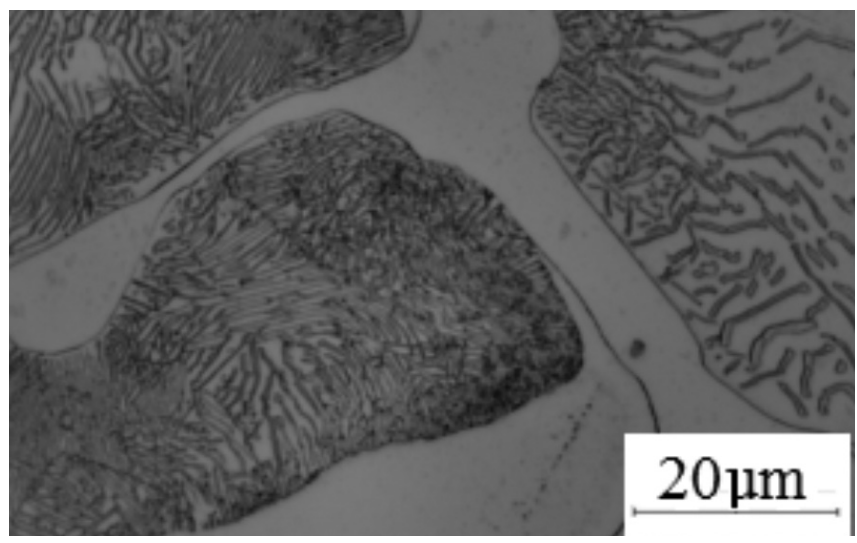

Fig. 5. The microstructure of the base material - AZ91 magnesium alloy

Rys. 5. Mikrostruktura materiału rodzimego - stop magnezu AZ91

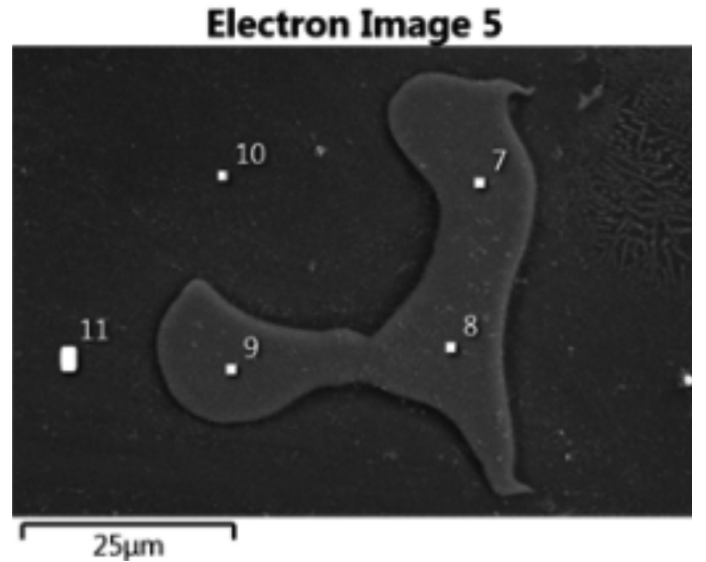

Fig. 6. The microstructure of base material with marked points of chemical analysis

Rys. 6. Mikrostruktura materiału rodzimego z zaznaczonymi punktami, w których wykonana została analiza chemiczna 
The observed microstructure of base material was subjected to the chemical analysis and line scan. Chemical analysis was performed in points marked on the microstructure shown in Fig. 6.

The results of the chemical analysis are shown in Table 2.

Table II.The results of the chemical analysis

Tablica II. Wyniki analizy chemicznej

\begin{tabular}{|c|c|c|c|c|}
\hline \multicolumn{2}{|c|}{} & \multicolumn{3}{|c|}{ Atomic \% } \\
\cline { 3 - 5 } \multicolumn{2}{|c|}{} & $\mathbf{M g}$ & Al & Zn \\
\hline \multirow{4}{*}{$\begin{array}{c}\text { Number of } \\
\text { point }\end{array}$} & 7 & 62,67 & 35,67 & 1,65 \\
\cline { 2 - 5 } & 8 & 63,33 & 34,98 & 1,69 \\
\cline { 2 - 5 } & 9 & 62,90 & 35,65 & 1,45 \\
\cline { 2 - 5 } & 10 & 95,01 & 4,99 & - \\
\cline { 2 - 5 } & 11 & 92,02 & 7,91 & - \\
\hline
\end{tabular}

The microstructure of base material and results of line scan are shown in Fig. 7.

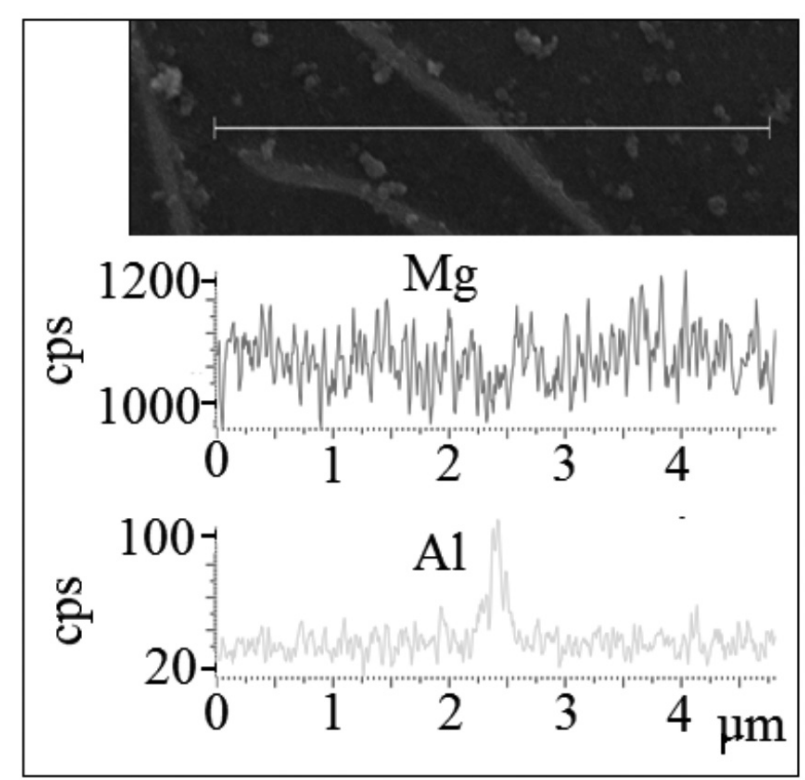

Fig. 7. The microstructure of base material and the results of line scan

Rys. 7. Mikrostruktura materiału rodzimego oraz wyniki analizy liniowej

Tensile test diagrams received in tensile testing of base material are shown in Fig. 8.

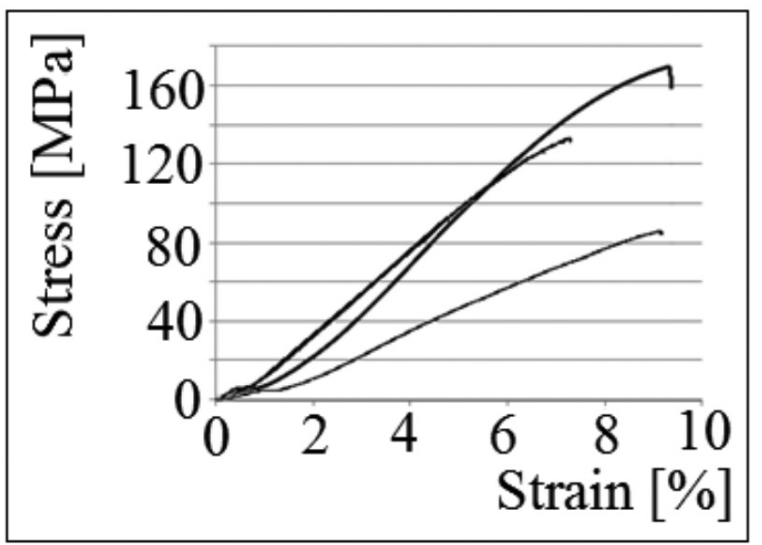

Fig. 8. The tensile test diagrams received in tensile testing Rys. 8. Wykresy uzyskane w wyniku jednoosiowej próby rozciągania
Table III. The values of tensile strength of base material

Tablica III. Wartości wytrzymałości na rozciąganie materiału rodzimego uzyskane w wyniku próby jednoosiowego rozciągania

\begin{tabular}{|c|c|c|c|}
\hline \multicolumn{4}{|c|}{ Base material } \\
\hline $\begin{array}{c}\text { Number of } \\
\text { specimen }\end{array}$ & 1 & 2 & 3 \\
\hline Rm [Mpa] & 133 & 86 & 169 \\
\hline
\end{tabular}

The filler material was extracted from the same magnesium alloy $A Z 91$.

\section{Preparation for welding}

The 141 (TIG) and 522 (laser gas welding) methods were used for welding. The parts prepared for welding by 141 method are shown in Fig. 9.

The parts prepared for welding by 522 method are shown in Fig. 10.

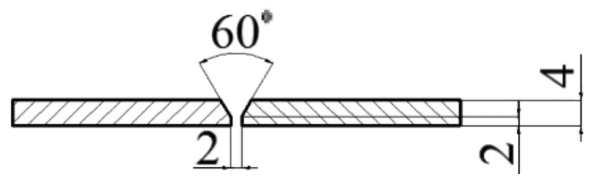

Fig. 9. The parts prepared for TIG welding

Rys. 9. Brzegi materiału rodzimego przygotowane do spawania TIG

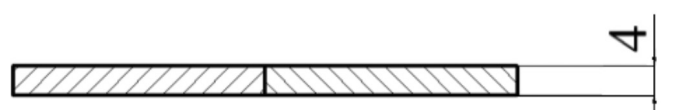

Fig. 10. The parts prepared for laser gas welding

Rys. 10. Brzegi materiału rodzimego przygotowane do spawania laserowego

WPS was written during the period of preparing to welding. The selected parameters of welding are shown in Table 4 (141 method) and Table 5 (522 method).

Table IV. The selected parameters of TIG welding Tablica IV. Wybrane parametry spawania TIG

\begin{tabular}{|c|c|}
\hline Polarity & $\mathrm{DC},(+)$ \\
\hline Amperage & $30 \mathrm{~A}$ \\
\hline Welding travel speed & $0,05 \mathrm{~m} / \mathrm{min}$ \\
\hline Shielding gas type & Argon \\
\hline Preheat temperature & $200{ }^{\circ} \mathrm{C}$ \\
\hline Interpass temperature & $200-300{ }^{\circ} \mathrm{C}$ \\
\hline Filler & AZ91 \\
\hline
\end{tabular}

Table V. The selected parametrs od laser gas welding Tablica V. Wybrane parametry spawania laserowego

\begin{tabular}{|c|c|}
\hline Power & $2 \mathrm{~kW}$ \\
\hline Welding travel speed & $3 \mathrm{~m} / \mathrm{min}$ \\
\hline Shielding gas type & Helium \\
\hline Preheating temperature & Parts was not preheated \\
\hline Filler & Welding without filler \\
\hline
\end{tabular}

\section{Welded joints}

\section{Laser gas welding (522)}

The macrostructure of joint welded by 522 method is shown in Fig. 11. 


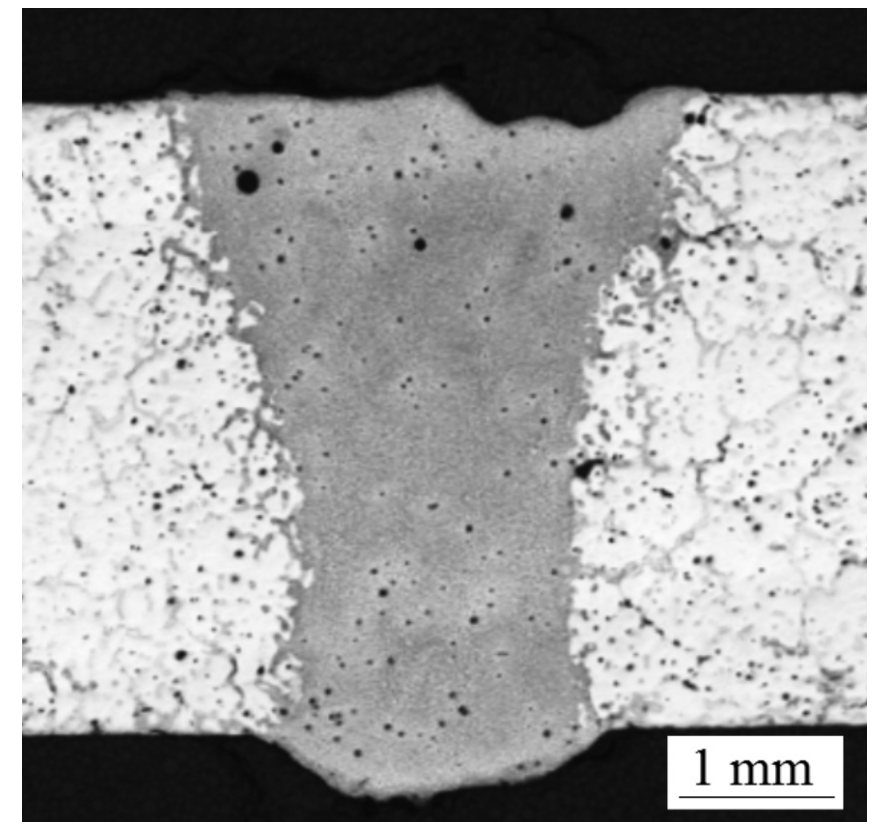

Fig. 11. The macrostructure of joint welded by 522 method Rys. 11. Makrostruktura złącza spawanego metodą 522

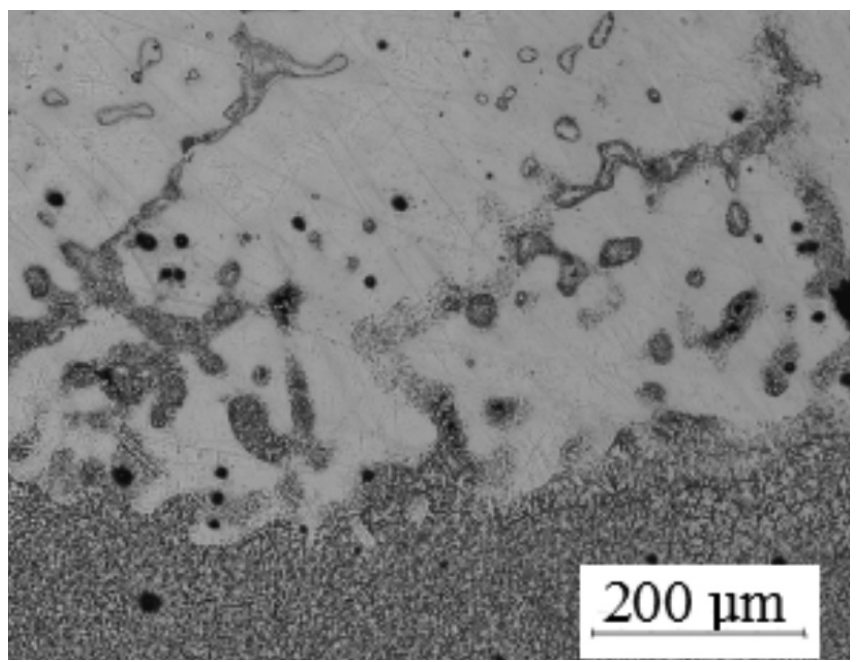

Fig. 12. The line of fusion

Rys. 12. Linia wtopienia

The microstructure of joint is shown in Fig. 13 and Fig. 14. The microstructure in the line of fusion was subjected to the chemical analysis. The chemical analysis was performed in points marked on the microstructure shown in Fig. 15.

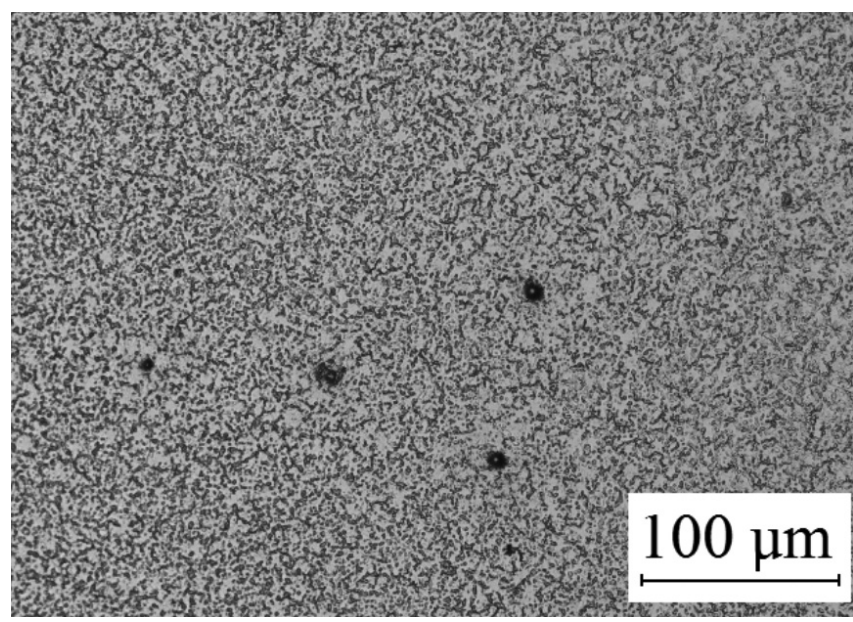

Fig. 13. The microstructure of the joint

Rys. 13. Mikrostruktura spoiny

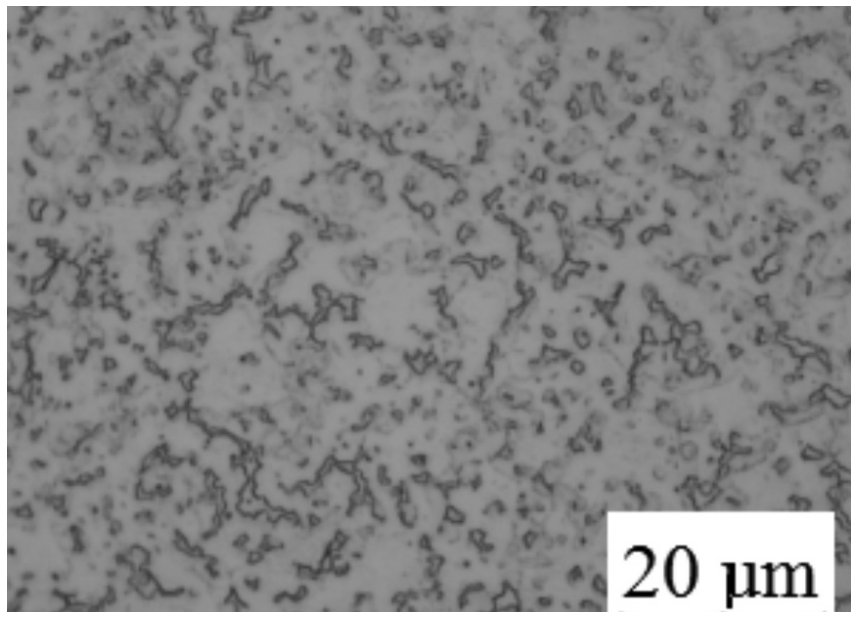

Fig. 14. The microstructure of the joint

Rys. 14. Mikrostruktura spoiny

\section{Electron Image 2}

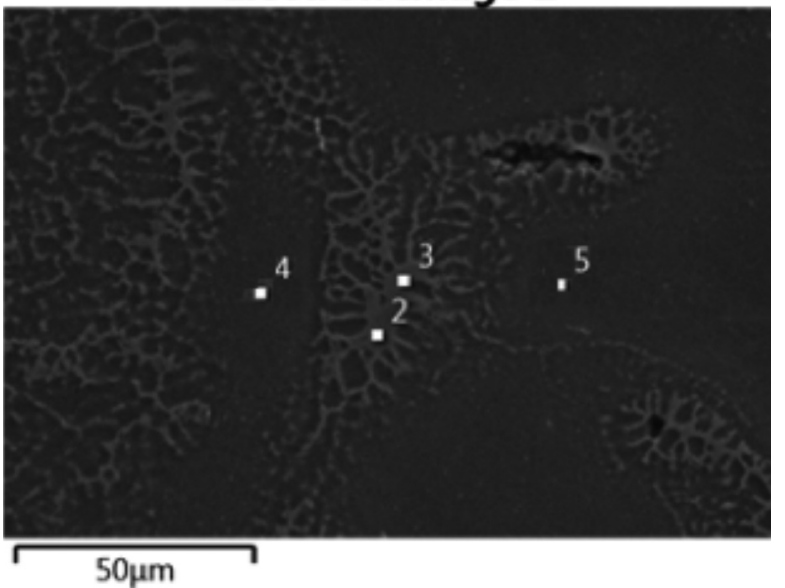

Fig. 15. The microstructure of line of fusion with marked points of chemical analysis

Rys. 15. Mikrostruktura linii wtopienia z zaznaczonymi punktami, w których wykonywana była analiza chemiczna

The outcome of the chemical analysis are shown in Table 6 . Tensile test diagrams received by tensile testing of connection welded by 522 method are shown in Fig. 16.

Table VI.The results of the chemical analysis Tablica VI. Wyniki analizy chemicznej

\begin{tabular}{|c|c|c|c|c|}
\hline \multicolumn{2}{|c|}{} & \multicolumn{3}{|c|}{ Atomic \% } \\
\cline { 3 - 5 } \multicolumn{2}{|c|}{} & $\mathbf{M g}$ & Al & Zn \\
\hline \multirow{3}{*}{$\begin{array}{c}\text { Number of } \\
\text { point }\end{array}$} & 2 & 68,4 & 30,21 & 1,39 \\
\cline { 2 - 5 } & 3 & 69,56 & 29,14 & 1,30 \\
\cline { 2 - 5 } & 4 & 94,66 & 5,34 & - \\
\cline { 2 - 5 } & 5 & 94,65 & 5,35 & - \\
\hline
\end{tabular}

Table VII.The values of tensile strength of specimens from joint weIded by 522 method

Tablica VII. Wartości wytrzymałości na rozciąganie próbek ze złącza spawanego metodą 522

\begin{tabular}{|c|c|c|c|}
\hline \multicolumn{4}{|c|}{ Joint welded by $\mathbf{5 2 2}$ method } \\
\hline $\begin{array}{c}\text { Number of } \\
\text { specimen }\end{array}$ & 1 & 2 & 3 \\
\hline Rm [Mpa] & 135 & 135 & 138 \\
\hline
\end{tabular}




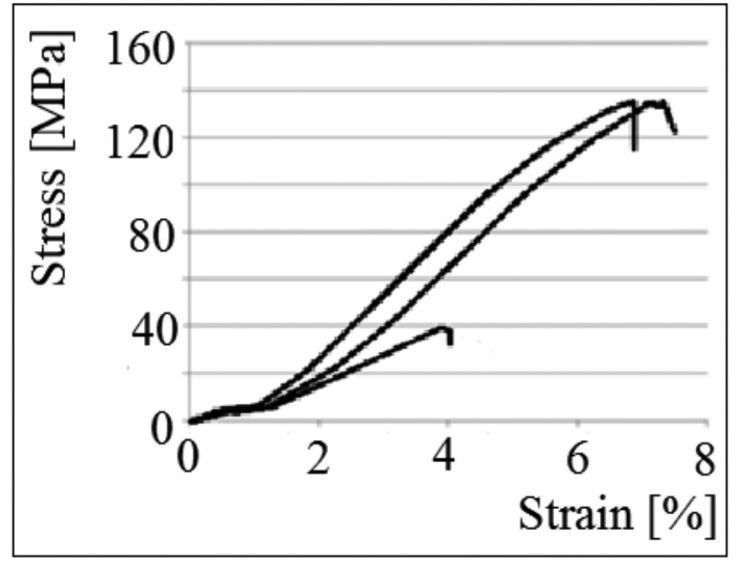

Fig. 16. Tensile test diagrams received by tensile testing of connection welded by 522 method.

Rys. 16. Wartości wytrzymałości na rozciąganie uzyskane w wyniku próby jednoosiowego rozciągania złącza spawanego metodą 522

The values of tensile strength of tested specimens are shown in Table 7.

\section{TIG (141)}

The macrostructure of joint welded by 141 method is shown in Fig. 17.

The microstructure of joint is shown in Fig. 18 and Fig. 19.

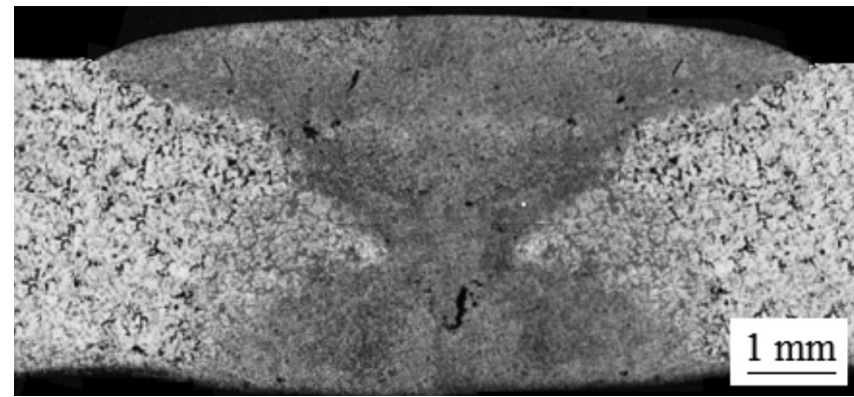

Fig. 17. The macrostructure of joint welded by 141 method Rys. 17. Makrostruktura złącza spawanego metodą 141

Table VIII. The values of tensile strength of specimens from joint welded by 141 method

Tablica VIII. Wartości wytrzymałości na rozciąganie próbek ze złącza spawanego metodą 141

\begin{tabular}{|c|c|c|c|}
\hline \multicolumn{4}{|c|}{ Joint welded by 141 method } \\
\hline $\begin{array}{c}\text { Number of } \\
\text { specimen }\end{array}$ & 1 & 2 & 3 \\
\hline Rm [Mpa] & 146 & 137 & 104 \\
\hline
\end{tabular}

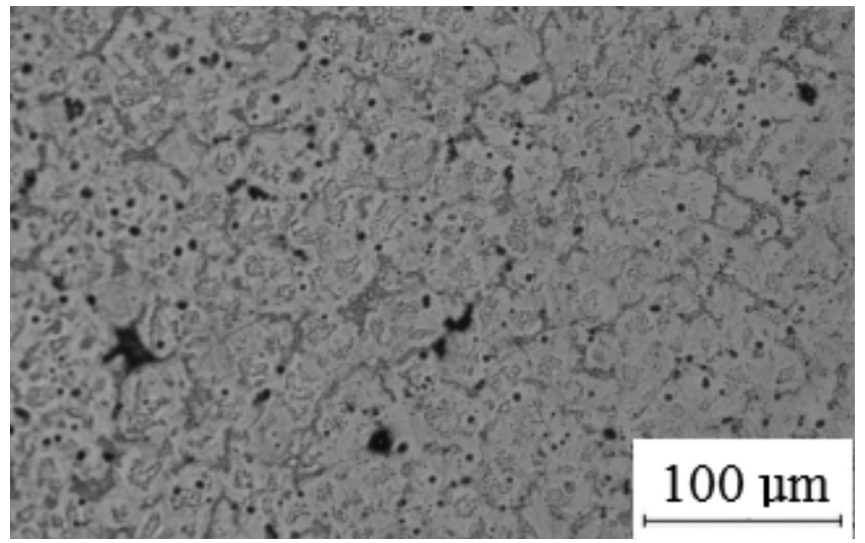

Fig. 18. The microstructure of joint welded by 141 method Rys. 18. Mikrostruktura spoiny

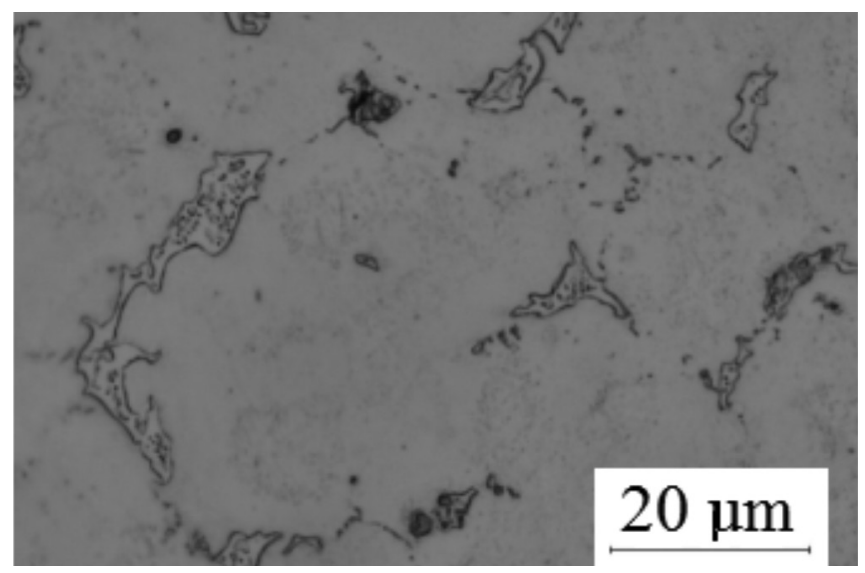

Fig. 19. The microstructure of joint Rys. 19. Mikrostruktura spoiny

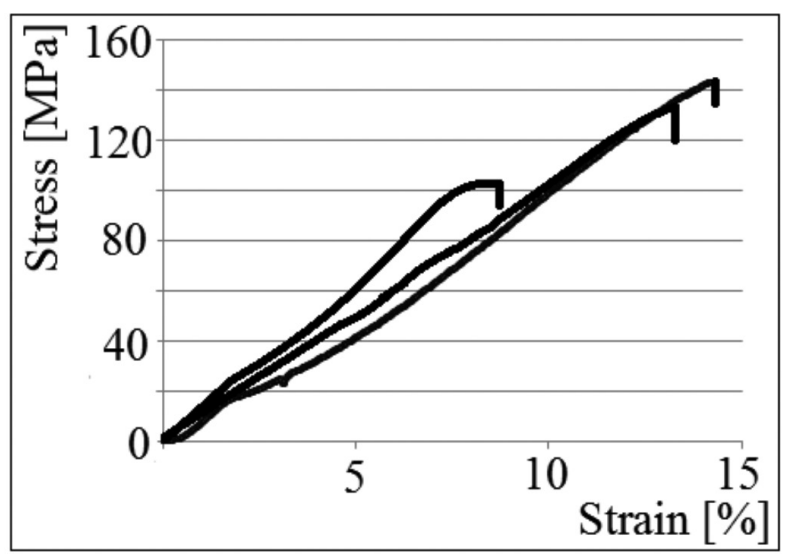

Fig. 20. Tensile test diagrams received by tensile testing of connection welded by 141 method

Rys. 20. Wartości wytrzymałości na rozciąganie uzyskane w wyniku próby jednoosiowego rozciągania złącza spawanego metodą 141

\section{Discussion and conclusions}

The phase, solid solution aluminum-magnesium and alternately arranged precipitations of solid solution aluminum-magnesium are observed in the microstructure of the base material [5]. The morphology and chemical composition of observed microstructure confirm that.

The microstructural changes were not observed in the base material adjacent to joint. Magnesium alloy AZ91 should be heated several dozen hours in $420^{\circ} \mathrm{C}$ to alter the microstructure [5]. The approximate time of influence of that temperature 
in the base material close to joint during welding process was several minutes. The time is not sufficient to draw the microstructural changes in this type of magnesium alloy.

Tensile test pieces which were extracted from welded joints which were fractured in the base material in majority of cases. It proves that the joint has the higher tensile strength than the base material. The crystals in joints are small and they have fewer impairments than conventional cast. The secondary microstructure which is related to phase transitions is presents in joints. It has positive effect on the mechanical properties of welding connection.

The scattered welding imperfections caused the fracturing in the joint of only one specimen welded by 141 and one weIded by 522.

The single gas inclusions in the joints occur because of gases dissolved in liquid metal and their emission. Solubility of gases in liquid metal decline when the temperature lowers. Emitted gases have not enough time to leave the joint because the decrease of temperature during the welding process is sharp. Gases stay in the joint and make the gas inclusions [3].

The zone of fusion is more concentrated in case of the 522 welding method due to the focused laser beam and the high intensity of process. This intensity has also effect on dispersion of the eutectic which is observed in the joint. In case of the 522 method dispersion is much higher than in case of the 141 method.

Eutectic which include solid solution aluminium-magnesium and phase is observed in the microstructure of joint. It is confirmed by the morphology and the chemical composition of microstructure of joint.

\section{References}

[1] P. Kołodziejczak, A. Kolasa, K. Skrzyniecki, P. Cegielski: Spawanie stopu magnezu z grupy AM metodą MIG. Przegląd Spawalnictwa vol. 85, nr 11 s. 36-40, 2013.

[2] L. Tuz, P. Kołodziejczak, A. Kolasa: Struktura złączy doczołowych odlewniczych stopów magnezu, Przegląd Spawalnictwa vol 83, nr 7, s. 51-55, 2011.

[3] J. Pilarczyk et al: Spawalnictwo, Warszawa 2003

[4] http://www.hindawi.com/journals/amse/2013/170527/fig2/

[5] A. Dziadoń: Magnez i jego stopy, Kielce 2012.

K. Przybyłowicz: Metaloznawstwo, Warszawa 2007.

[6] K. Przybyłowicz: Metaloznawstwo, Warszawa 2007.

[7] F. Friedrich, S. Schuman: Research for a "new age of magnesium in the automotive industry, Journal of Materials Processing Technology 117 276-281, 2001

[8] X. Cao, M. Jahazi, J.P. Immarigeon, W. Wallace: A review of laser welding techniques for magnesium alloys, Journal of Materials Processing Technology 171, 188-204, 2006.

[9] A. Abdel: Protective coating for magnesium alloy, Journal of Materials and Science 43, 2947-2954, 2008.

[10] F. Vesling, T. Ryspaev: „Effect of heat treatment on the super plasticity of magnesium alloys, Russian Journal of Non-Forrous Metals 48, 57-62, 2007.

[11] C. Lehner, G. Reinhart, L. Schaller. „Welding of die-casted magnesium alloys for production, Journal of Laser Applications 11/5, 206-210, 1999. 